\title{
CHOV PRASAT VE STŘEDOVĚKU PRIZMATEM STABILNÍCH IZOTOPU゚ UHLÍKU A DUSÍKU
}

\author{
OLGA TROJÁNKOVÁ - LENKA KOVAČIKOVÁ - JAN FROLÍK - PETR STAREC - \\ JARMILA ČIHÁKOVÁ
}

\begin{abstract}
Abstrakt: Př́spěvek rozšiřuje dosavadní poznatky o chovu prasat domácích (Sus domesticus) ve středověku, přičemž se zaměřuje předevšim na výżivu a režim krmeni těchto pro středověkou ekonomiku významných hospodárských zviŕat vodlišném sociálním prostředí a čase. V minulosti popsané výsledky archeozoologické analýzy jsou kombinovány se zjištěnimi plynoucimi z analýzy dvou stabilnich izotopů biogennich prvků uhliku a dusíku. Předmět našeho zájmu tvoři tři středověké lokality z územi dnešni Prahy reprezentujici širši časové rozmezi od 9. do 14. století. Srovnáni výsledků s daty z raně středověkých lokalit, kde předpokládáme převažujici extenzivni chov prasat, pomáhá bliže charakterizovat chovatelské strategie především ve vztahu k pražské raně středověké aglomeraci.
\end{abstract}

Klíčová slova: prase domácí-management chovu-středověk - archeozoologie-izotopová analýza.

\section{The breeding of pigs in the Middle Ages through the prism of stable isotopes of carbon and nitrogen}

\begin{abstract}
This contribution expands the existing information about the breeding of the domestic pig (Sus domesticus) in the Middle Ages, with emphasis on the nutrition and feeding regime of these farm animals so important for medieval economy, in different social environments and periods. Results of archaeozoological analysis published in the past were combined with findings from the analysis of two stable isotopes of biogenic elements - carbon and nitrogen. The research centred on three medieval sites in the territory of today's Prague spanning a broad chronological period, from the 9th century until the 14th century. The comparison of the results with data from early medieval sites where predominantly extensive pig breeding is presumed helps characterize breeding strategies, especially in relation to the early medieval agglomeration of Prague.
\end{abstract}

Key words: domestic pig - breeding management-Middle Ages - archaeozoology - isotope analysis.

\section{Úvod}

Analýza zvířecích kosterních pozůstatků z archeologických nalezišt' (archeozoologie) představuje kritický obor umožňující pochopení širších vzorců vztahů životního prostředí a sociální oblasti (Pilaar Birch 2013, 81). Zvířecí kosti a zuby objevené při archeologických výzkumech patří k nejběžnější skupině studovaných nálezů. Současný archeozoologický výzkum se zaměřuje kromě informací makroskopicky odčitatelných z kosterních pozůstatků přímo při jejich identifikaci (např. druh, anatomie nebo malformace) také na vyhodnocování shromážděných souborů dat (např. rozměry kostí, odhady věku dožití zvířat). V posledních letech se archeozoologické nálezy stávají čím dál častěji předmětem analytických chemických metod, například analýzy stabilních izotopů. Všechny závěry, které se podaři shromáždit ke konkrétnímu nálezovému celku, pak představují vhodný základ pro zvýšení jeho informačního potenciálu. Důvodem integrace výsledků měření stabilních izotopů do archeozoologického výzkumu je snaha bliže charakterizovat paleoekologické podmínky a interakce mezi potravními zdroji lidí a zvírat v čase a prostoru (Zangrando et al. 2014, 127). Při interpretacích izotopových měření má nespornou důležitost porozumění ekologii, fyziologii a vývoji kostí u sledovaných druhů zvířat (Pilaar Birch 2013, 81). Mezi externí faktory, které až ze 40 \% ovlivňují růstové parametry zvířat a jejich produkci, patří výživa (Šarapatka-Urban 2006, 411). Studium výživy a potažmo i prostředí, v němž byla zvířata chována, může přispět $\mathrm{k}$ hlubší interpretaci hospodářské situace minulých populací a lépe dokumentovat sílu vazby mezi člověkem a zvířaty (Hammond-O'Connor 2013; Balasse et al. 2018). Prasata, jakožto všežravci s vysokou mírou adaptability na nejrůznější prostředí, mohou být chována ve výrazně odlišných podmínkách, které lze přiblížit na základě charakteristiky jejich krmiva. Na složení potravy mohou 
poukázat výsledky analýzy některých stabilních izotopů, např́ílad uhlíku a dusíku (Balasse et al. 2018, 82). Oba jmenované izotopy, které se ukládají v kostní tkáni a přetrvávají v ní i po smrti zvířete (napr. Hedges-Stevens-Koch 2006), jsou měřitelné.

Chov prasat domácích (Sus domesticus) tvořil ve středověké Evropě významnou součást živočišné produkce (např. Albarella 2006; O’Connor 2010). Jako jeho výhody jsou již tradičně zmiňovány vysoká adaptabilita prasat na různá prostředí, velký počet mlád’at ve vrzích, schopnost konzumace potravinových zbytků z domácností a zemědělské činnosti, produkce masa vhodného pro dlouhodobější uchování nebo hnoje využívaného pro zúrodňování půd (Albarella 2006, 72-73). Ve vztahu k raně středověké společnosti bývá také zmiňována souvislost mezi množstvím nálezů kostí a zubů těchto zvířat a společenským statusem obyvatel daných lokalit (Ashby 2002, 41; Albarella 2006, 80; Crabtree 2010, 129-130; Sirignano 2014, 143). Prase domácí, na rozdíl od skotu či ovcí a koz, neposkytuje sekundární produkty (vyjma hnoje) a jeho chov je zaměřen na produkci masa a tuku. Z této perspektivy může být chov prasat považován za určitý znak přepychu (Grant 2002, 18). Vyšší výskyt jeho kosterních pozůstatků na archeologických lokalitách bývá rovněž spojován se snahou uživit početnější populace, at' už na dlouhodobě existujících či nově vznikajících sídlištích (Albarella 2004, 145; Iwaszuk 2014, 86), nebo zajistit dostatek potravy v dobách nestabilní politické situace (O’Connor 2010,13).

Na území České republiky se setkáváme s početnými nálezy kostí a zubů prasat na raně středověkých sídlištích, často na hradištích. Dosud je tento fenomén znám převážně z oblasti středních a jižních Čech a Moravy. Osteologické soubory, ve kterých nálezy prasat převažují nad kostmi ostatních hospodářských savců, pochází v Čechách například z hradiště ve Staré Boleslavi (Kyselý 2003, 314; Mlíkovský 2003, 349), z Budče a Hradska (Peške 1985, tab. 1 na s. 211), Netolic (Hausteinová 2015, 32) nebo z území raně středověké Prahy (např. Boháčová a kol. 1990, 179; Kyselý 2015, 431; Kovačiková a kol. 2019, tab. 1 na s. 536). Na Moravě pak z Olomouce (Bláha 2000, 66; 2000a, 103), ohrazeného areálu v Pohansku (Dreslerová 2018, 25, 105) nebo Mikulčic (Kratochvíl 1978, tab. 3 na s. 58; Chrzanowska-Januszkiewicz-Załęcka 2003, 124; Hladík 2014, 175, tab. 28 na s. 177).

Kosterní nálezy prasat jsou významně zastoupeny také v některých souborech z vrcholně středověkých měst (Petřičková 2002; Baloghová 2010). Přestože se u velké části těchto souborů nesetkáváme s tak početným zastoupením kostí prasat jako u raně středověkých souborů, existuje řada výjimek. Ve dvou jímkách z vrcholně středověké Chrudimi tvořily pozůstatky prasat výraznou většinu kosterních nálezů (Baloghová 2010, 10,28), stejně tak bylo sledováno dominantní zastoupení kostí prasat v sídlištních vrstvách ze 13. století v Chebu (Šamata a kol. 2001, 12) nebo ve výplni studny z konce 14. století v Českých Budějovicích (Miklová 2019, 38).

\section{Tradiční chov prasat}

Etnografické studie věnované tradičnímu chovu prasat, navíc často z odlišných geografických oblastí, lze jen stěží využít jako přímé analogie pro středověkou společnost (Albarella et al. 2007, $285,304)$. Nicméně tyto práce často nahlížejí na určité aspekty chovu prasat, které vycházejí z biologické podstaty druhu, a proto mohou být do určité míry využity v archeozoologickém výzkumu. Na základě studia etnografických a historických zpráv definoval M. D. Price (2016, 73-74) ve své disertační práci pět modelů chovu prasat. Ty se liší především v druhu a míře nezbytných zásahů do chovu a ve výši investice chovatele. Ustanovené modely jsou zobecňující a slouží především pro vytvoření představy, jak variabilní může chov prasat být, at' už z hlediska mobility, krmiva, reprodukce či jiných hledisek. Uvnitř jednoho hospodářství se mohou př́stupy lišit nebo dochází k jejich vzájemnému prolínání.

Pro prasata domácí je výhodný venkovní (extenzivní) chov, nebot' jsou tak méně stresovaná, odolnější a přirozeně zdravější. Zároveň je jejich fyziologie a stavba těla předurčuje k přirozenému pohybu v kombinovaném prostředí - převážně v lesních oblastech a přilehlých polích, loukách nebo pastvinách, kde nalézají dostatečně rozmanitou potravu. Protože je prase citlivé na některé složky slunečního záření, má potřebu vyhledávat stinná místa pro úkryt (Šarapatka-Urban 2006, 
405-406). Pro extenzivní chov prasat vyčlenil M. D. Price (2016, 81-91) tři modely: volnou pastvu (free-ranging), vyhánění na pastvu (swine herding) a shánění potravy uvnitř sídelních areálů (urban scavenging).

Volná pastva prasat, jak byla donedávna praktikována např́ílad na ostrovech Sardinie a Korsika (Albarella et al. 2007), v Řecku (Halstead-Isaakidou 2011) či ve Španělsku (Hadjikoumis 2012), je model výrazně závislý na bohatosti potravní nabídky př́rodních stanovišt'. Potrava zvířat je sezónně proměnlivá z hlediska kvality a množství. Tento způsob chovu často vyžaduje rozsáhlé pozemky (až 50 ha) a dostupnost vodního zdroje, přičemž prasata domácí jsou ponechána zcela volně, aby si sama sháněla potravu (Albarella et al. 2007, 300). Často dochází k jejich kř́ížení s divoce žijícími prasaty, přičemž přístup chovatelů k těmto křížencům se v jednotlivých oblastech liší (Halstead-Isaakidou 2011, 163; Albarella et al. 2007, 299). Z hlediska vkladu majitele představuje volná pastva nejméně náročnou variantu. Chovatel soustředí svou pozornost především na ochranu samic $\mathrm{v}$ době porodu a laktace, snaží se předcházet střetu s predátory, chránit zemědělské plodiny před poškozením prasaty, například oplocením pozemků či aplikací kovových kruhů do nozder zvířat, aby jim bylo zabráněno v rytí (Albarella et al. 2007, 303), nebo obstarává doplňkové krmivo mimo sezónu lesních plodů (Albarella et al. 2007, 303, tab. 16.1 na s. 294-297; Hadjikoumis 2012, 359).

Model volné pastvy prasat bývá kombinován s vyháněním zvířat do lesů, a to především v období podzimu a zimy, kdy zde vyhledávají žaludy nebo jiné lesní plody (Hadjikoumis 2012, 359; Halstead-Isaakidou 2011, 166). V některých oblastech může probíhat tato kontrolovaná pastva i celoročně (Halstead-Isaakidou 2011, 164). Krmivo doplňované chovatelem může být rostlinného (napřr. obiloviny, luštěniny, nasbírané plody) a živočišného původu (např. mléko, syrovátka) či jejich kombinací (zbytky z domácností).

Posledně jmenovaný případ reprezentuje chov prasat v režimu volné pastvy v obydlených oblastech (Price 2016, 89). Tento způsob, v moderní době praktikovaný např́́klad na území Indie, je znám spíše z historických pramenů (Albarella 2006, 79; Jørgensen 2013) než z etnografických studií (Price 2016, 90). Pro prostředí evropských středověkých měst se v historické literatuře objevují informace o pohybu prasat na veřejných prostranstvích, kde se starala o likvidaci komunálního odpadu, přičemž se jednalo spíše o jednotky kusů, které patřily obyvatelům města (Leguay 1999, 20-22; Dvořáková 2015, 461; Šedivý 2015, 484). Na př́ítomnost zbytků steliva pro dobytek nebo hnůj uvnitř města ukazují také výsledky analýzy rostlinných makrozbytků, pylových zrn nebo parazitů (Havrda a kol. 2017, 175-185). M. D. Price (2016, 89-91) klasifikuje tento model ještě stále jako extenzivní, a to z důvodu minimální kontroly věnované reprodukci, obstarávání potravy i mobilitě zvířat, i když tyto závěry jsou z důvodu nedostatku pramenů, jak sám autor uvádí, spíše v rovině domněnek.

Na druhém konci spektra způsobů managementu se nachází intenzivní chov prasat, například v ohradách a stájích. Ten sice vyžaduje výraznější vklad a investice chovatele, není ale tak náročný na prostor a zvířata se daří rychleji vykrmit do požadované váhy (Price 2016, 79). Mezi další výhody intenzivního chovu prasat domácích patří zamezení jejich křížení s prasaty divokými a ničení zemědělsky využívaných ploch či produkce hnoje, jehož aplikací do půd je na straně jedné zvyšováno množství dostupných živin využitelných pěstovanými rostlinami, na straně druhé ale může zapříčiňovat kontaminaci vodních zdrojů v zasídlených oblastech. Obvykle je krmivo podávané intenzivně chovaným prasatům velmi variabilní a je složeno z rostlinného a živočišného odpadu z domácností, pomejí, speciálně namíchaného krmiva, odpadních produktů ze zemědělství, nasbíraných lesních plodů atd. (Blair 2007, 61-65; Price 2016, 78). V některých oblastech jsou i tímto způsobem chovaná prasata vyháněna na pastvu (Halstead-Isaakidou 2011, 166).

\section{Analýza stabilních izotopů spojená s chovem hospodářských zvíŕat}

Poměry stabilních izotopů uhlíku a dusíku $\left({ }^{13} \mathrm{C} /{ }^{12} \mathrm{C},{ }^{15} \mathrm{~N} /{ }^{14} \mathrm{~N}\right)$, tj. poměry četnosti těžšího izotopu k četnosti izotopu lehčího (Květoň 2018, 29), uložených ve vzorcích organické složky (kolagenu) 
zubů prasat domácích, kterým je věnován tento příspěvek, odrážejí izotopové poměry v jejich potravě a zároveň zohledňují frakcionaci, k níž dochází v průběhu reakcí (DeNiro 1987). V suchozemských rostlinách, které tvoří součást výživy prasat (Blair 2007, 61-65), se liší hodnoty poměru těžkého a lehkého izotopu uhlíku v závislosti na způsobu zabudování uhlíku z $\mathrm{CO}_{2}$ do organických látek, tj. na fotosyntetické asimilaci (Smith-Epstein 1971; O’Leary 1988). Izotopová diskriminace uhlíku většiny suchozemských rostlin, kterých je v našich zeměpisných šiřkách historicky většina, odpovídá $\mathrm{C}_{3}$ typu fotosyntézy (Kohn 2010). Rostliny s $\mathrm{C}_{4}$ typem asimilace $\mathrm{CO}_{2}$ (Smith-Epstein 1971; O’Leary 1988) u nás tvoří jen velmi malý podíl rostlinné biomasy a pro období středověku připadá v úvahu např́íklad proso seté (Panicum miliaceum), o jehož záměrném pěstování existují doklady už v eneolitu (např. Hajnalová 1999, 52). Hodnoty stabilního izotopu uhlíku mohou rovněž přiblížit, zda byla vegetace spásána ve vlhkých a zastíněných lesních biotopech nebo na otevřených a suchých stanovištích (Drucker et al. 2008; Somerville-FroehleSchoeninger 2018, 93).

U omnivorních prasat lze vedle rostlinné složky v potravě očekávat také bílkovinné komponenty živočišného původu, proto může být jejich kostní a zubní kolagen obohacen o izotopy dusíku (DeNiro-Epstein 1981). Hodnoty $\delta^{15} \mathrm{~N}$ rostou s každou trofickou úrovní přibližně o 3-5 \% (Bocherens-Drucker 2003). Primárním zdrojem dusíku v půdách jsou dusičnany, dusitany a amonné ionty, které přijímají rostliny. Některé rostliny mají navíc schopnost asimilovat molekulární dusík z atmosféry (Šimek-Hynšt 2019, 548). Izotopový signál půd se mění v závislosti na mnohých faktorech, např́klad typu a stáří půdy, složení rostlinných společenstev nebo klimatických podmínkách (Pardo-Nadelhoffer 2010, 229-235; Somerville-Froehle-Schoeninger 2018, 92). Vliv na něj mají také některá agrotechnická opatření. Např́klad hnojení zvyšuje obsah $\delta^{15} \mathrm{~N}$ v zemědělských plodinách, které mohou být využity jako krmivo pro hospodářská zvířata (Bogaard et al. 2007; Fraser et al. 2011).

Tabulka 1. Přehled minimálních a maximálních hodnot $\delta^{13} \mathrm{C}$ a $\delta^{15} \mathrm{~N}$ naměřených ve vzorcích zubního kolagenu prasat domácích (Sus domesticus) ze všech stř̌edověkých lokalit zahrnutých do této studie.

Tabelle 1. Übersicht der in den Zahnkollagenproben von Hausschweinen (Sus domesticus) gemessenen Mindest- und Höchstwerte von $\delta^{13} \mathrm{C}$ und $\delta^{15} \mathrm{~N}$ von allen in vorliegende Studie aufgenommenen Fundstellen.

\begin{tabular}{|c|c|c|c|c|c|c|c|}
\hline Lokalita & Datování & $\begin{array}{c}\text { Počet } \\
\text { vzorků }\end{array}$ & $\underset{(\%)}{\operatorname{Min} \delta^{13} \mathrm{C}}$ & $\begin{array}{c}\operatorname{Max} \delta^{13} \mathrm{C} \\
(\% 0)\end{array}$ & $\begin{array}{c}\operatorname{Min} \delta^{15} \mathrm{~N} \\
(\% 0)\end{array}$ & $\begin{array}{c}\operatorname{Max} \delta^{15} \mathrm{~N} \\
(\% 0)\end{array}$ & Reference \\
\hline $\begin{array}{l}\text { Malostranské náměstí } \\
\text { čp. } 2 \text { /III }\end{array}$ & 9.-11. století & 24 & $-22,4$ & $-19,9$ & 4,8 & 9,1 & \multirow{3}{*}{$\begin{array}{c}\text { Kovačiková a kol. } \\
\text { (2020a) }\end{array}$} \\
\hline $\begin{array}{l}\text { Pražský hrad - } \\
\text { Severní výběžek }\end{array}$ & 12. -13 . století & 19 & $-21,9$ & $-19,0$ & 4,5 & 9,5 & \\
\hline Křižovnická čp. 71/I & 13.-14. století & 23 & $-22,0$ & $-19,3$ & 5,8 & 11,2 & \\
\hline $\begin{array}{l}\text { Mikulčice } \\
\text { (předhradí) }\end{array}$ & 8. -9 . století & 25 & $-22,4$ & $-19,5$ & 4,6 & 11,4 & $\begin{array}{c}\text { Kovačiková a kol. } \\
(2020)\end{array}$ \\
\hline Roztoky & 6.-7. století & 22 & $-23,3$ & $-19,2$ & 4,7 & 9,3 & $\begin{array}{c}\text { Kovačiková } \\
\text { (nepublikovaná } \\
\text { data) }\end{array}$ \\
\hline
\end{tabular}

\section{Cíle}

Cílem tohoto př́íspěvku je porovnání zastoupení stabilních izotopů uhlíku $\left(\delta^{13} \mathrm{C}\right)$ a dusíku $\left(\delta^{15} \mathrm{~N}\right)$ v kořenech zubů prasat domácích ze tří pražských lokalit datovaných do 9. až 14. století (Malostranské nám. čp. 2/III, Pražský hrad - Severní výběžek, Křižovnická čp. 71/I) a dvou k nim zvolených referenčních osteologických souborů - Roztok (okr. Praha-západ) ze 6. až 7. století a Mikulčic (okr. Hodonín) z 8.-9. století (obr. 1). V našem prŕíspěvku jsme se 1) pokusili vymezit způsob 
chovu prasat, především jejich výživu a režim krmení v odlišném sociálním prostředí a čase (raný a vrcholný stř̌edověk), a to na základě srovnání výsledků analýz stabilních izotopů dusíku a uhlíku ve vzorcích z vybraných lokalit; 2) definovat, zda byl produkční systém chovu prasat domácích spíše extenzivní, nebo více kontrolovaný, což by se projevilo změnou v technice krmení, například vyvolanou zvyšující se poptávkou po vepřovém mase. Výsledky izotopových měření propojujeme se závěry publikovaných archeozoologických a paleobotanických studíi.

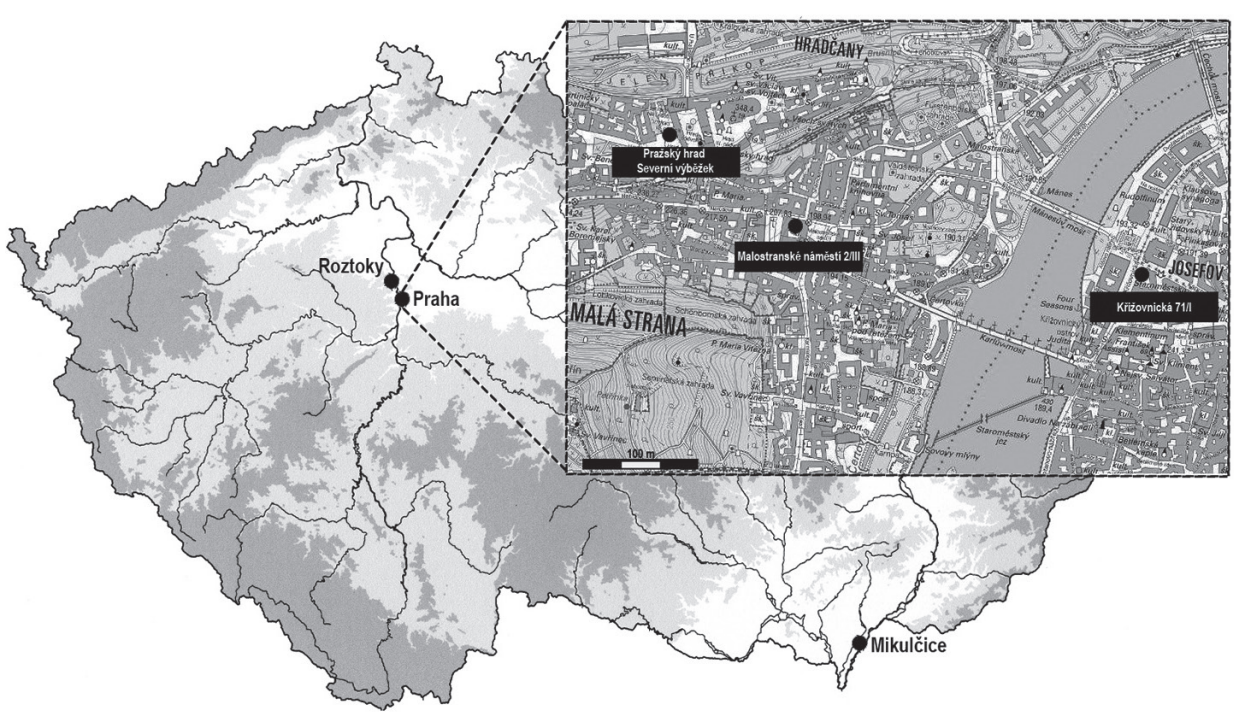

Obr. 1. Mapa s vyznačenými lokalitami zahrnutými do této studie. Praha - Malostranské náměstí čp. 2/III (9.-11. století), Pražský hrad - Severní výběžek (12.-13. století), Křižovnická čp. 71/I (13.-14. století); Mikulčice (8.-9. století); Roztoky (6.-7. století).

Abb. 1. Karte mit Kennzeichnung der in vorliegende Studie aufgenommenen Fundstellen Prag - Kleinseitner Platz Konskriptionsnr. 2/III (9.-11. Jahrhundert), Prager Burg - nördlicher Ausläufer (12.-13. Jahrhundert), Kreuzherrenstraße Konskriptionsnr. 71/I (13.-14. Jahrhundert); Mikulčice (8.-9. Jahrhundert); Roztoky (6.-7. Jahrhundert).

\section{Vybrané archeologické lokality}

V letech 2004-2005 byl realizován záchranný archeologický výzkum v centrální části Malostranského náměstí čp. 2/III, v prostorách bývalého profesního domu řádu jezuitů (Čiháková-Müller 2006). Na raně středověkém souvrství o mocnosti $1,3 \mathrm{~m}$ byla na konci 11 . století vybudována románská rotunda zasvěcená sv. Václavovi (Čiháková 2017, 90; 2017a, 232-235). Její stavbě předcházel vznik dalších dvou kostelních staveb, počátky jedné z nich jsou datovány př́ibližně do poloviny 10. století a jedná se o nejstarší doloženou křestanskou sakrální stavbu s kamenným základem v Praze vně Pražského hradu (Čiháková 2017a, 232-235). Výzkum stratigrafie pod planýrkou této stavby odhalil dřevěnou zástavbu - celkem šest postupně přestavovaných roubených konstrukcí v superpozici, z nichž ty nejstarší sloužily obytným a výrobním účelům (Čiháková 2017, 91; 2018, 296). První kostelní stavba z poloviny 10. století tak nebyla zbudována na volném prostranství, nýbrž na místě tradiční zástavby. Po zániku nejstarší kostelní stavby nejspíše provizoria, byl pro kostel, v pořadí druhý, navršen původně až $0,9 \mathrm{~m}$ vysoký násyp. $\mathrm{V}$ jeho složení převažoval materiál podloží promísený s materiálem z historických terénů. Ve skladbě nálezových souborů z násypu pod druhým kostelem a sídlištního souvrství pod prvním 
kostelem se objevují náznaky jisté sociální exkluzivity tohoto místa. Jedná se o drobné šperky, z nichž některé byly pozlacené, korálky z nášivky, nezvyklé kostěné čepelky, patrně sloužící $\mathrm{k}$ hygienickým účelům, nebo doklady práce se stř́brem. Zkoumané místo sousedilo minimálně do počátku 10. století s cestou, okolo roku 800 úvozového charakteru s kameny na dně a okolo roku 900 navýšenou, rozšířenou a opatřenou dřevěnou vozovkou. Stav cesty z doby existence zdejších kostelů není znám.

Archeozoologické nálezy odpovídající různým jedincům prasat domácích z výzkumu na Malostranském náměstí, které byly vybrány za účelem porovnání, byly datovány do 9 . až poloviny 11. století. Velikost souboru čítá 24 hodnot stabilních izotopů uhlíku a dusíku, které byly změřeny ve vzorcích kolagenu izolovaného ze zubních kořenů trvalé dentice (Kovačiková a kol. 2020a).

Záchranný archeologický výzkum v tzv. Severním výběžku, tj. palácovém křídle, které odděluje I. a IV. nádvoří Pražského hradu, proběhl v roce 1997 a zachytil až 1,5 m silné sídlištní souvrství. Do období 12.-13. století náleželo šest sídlištních horizontů, které se podařilo mezi jednotlivými sondami bez problémů synchronizovat. Kromě stratigrafie byla vodítkem pro vyčlenění keramika pražského okruhu. Jedná se o výsek z dynamicky se vyvíjející sídlištní situace s obytnými i hospodářskými objekty. Převážnou většinu horizontů zastupují pouze sídlištní vrstvy. Sídlištní objekty zjišt'ujeme v nejstarším sledovaném horizontu, kde byl zachycen objekt s kolmou stěnou zahloubený asi $0,5 \mathrm{~m}$ pod úroveň okolního terénu (objekt 724). S určitou opatrností ho interpretujeme jako polozemnici. Dalším objektem téhož horizontu je žlábek (objekt 703) a kůlová jamka (objekt 603). Nezuhelnatělé zlomky dřeva smrku, nalezené v žlábku, naznačují, že se jedná o základ stěny dřevěné stavby. Zkoumaná situace je součástí osídlení západního předhradí Pražského hradu. V blízkém okolí byl prozkoumán románský dům, datovaný do stejného období. Severovýchodně (ca $40 \mathrm{~m}$ ) se nachází nejstarší hradní kostel P. Marie s pohřebištěm (Frolík 1997; 2017, 221, 242-244). Nálezově se terény v Severním výběžku nevymykají situacím z jiných částí Pražského hradu (kostěná šídla a hroty, zlomek přeslenu, železný hřebík, amorfní zlomek bronzu). Méně obvyklý je pouze jednoduchý páskový prsten s rytou výzdobou v podobě vlnice nebo pecka z broskve (Hurajčíková 2014, 92-94, 98).

Zvířecí kosterní materiál z Pražského hradu - Severního výběžku byl datován do 12.-13. století a pro potřeby této studie bylo využito 19 hodnot stabilních izotopů uhlíku a dusíku obsažených v kolagenu zubních kořenů prasat domácích (Kovačiková a kol. 2020a).

V letech 2016-2017 proběhl záchranný archeologický výzkum ve sklepích činžovního domu zvaného Na Kocandě, Křižovnická čp. 71/I (Starec 2017; 2017a). V obou výzkumných sezónách byla postupně odkrývána hradební zed' Starého Města pražského, která byla založena v polovině 13. století v mírném svahu čela vltavské terasy (VIIc). Na vymezené ploše byl sledován průběh hradby $(26,5 \mathrm{~m})$. Průchod zajišt'ovala brána sv. Valentina, pojmenovaná podle blízkého románského kostela. Cesta z areálu města vedla k brodu na malostranský vltavský břeh. Dendrochronologicky byla první fáze brány datována do 40 . let 13 . století, její přestavba pak do období po roce 1272. V okolí brány a hradební zdi byly sledovány až dvoumetrové vrstvy sídlištního souvrství, které byly mimo jiné tvořeny hromaděním městského odpadu v průběhu 13. a 14. století. Dále byly postupným plošným odkryvem vymezeny relikty středověkých studní, zdiva a dalších objektů.

Kosterní pozůstatky prasat domácích z Kř́̌žovnické ulice čp. 71/I byly datovány do 13.-14. století a v této studii pracujeme s 23 hodnotami stabilních izotopů uhlíku a dusíku naměřenými ve vzorcích kolagenu z kořenů trvalé dentice (Kovačiková a kol. 2020a).

\section{Vybrané referenční soubory}

Raně stř̌edověké sídliště v Roztokách (okr. Praha-západ, střední Čechy) představuje lokalitu, kde bylo na ploše o minimální rozloze 22 ha zachyceno přes 300 zahloubených domů datovaných do kultury pražského typu (6.-7. století). V Roztokách nebyly prokázány objekty, které by jednoznačně dokládaly specializovanou výrobu nebo př́itomnost elity (Kuna a kol. 2013, 59-60). 
V archeozoologickém materiálu bylo vytipováno 22 trvalých zubů prasat domácích, které byly podrobeny analýze stabilních izotopů (Kovačiková, nepublikovaná data).

Velkomoravské hradiště v Mikulčicích (okr. Hodonín, jižní Morava) představovalo rozsáhlou a členitou sídelní aglomeraci s kontinuálním osídlením od pozdního 8. století s vrcholem na konci 9. století (Poláček 2016, 8). Plocha 103, pro kterou bylo k dispozici 25 izotopových měření (Kovačiková a kol. 2020), se nachází v areálu opevněného předhradí mocenského centra Mikulčice-Valy zkoumaného při předstihovém terénním archeologickém výzkumu v letech 2013-2014. Tato plocha datovaná do středohradištního období má povahu překrývajících se podlahových úprav písčitého a jílovitého charakteru pro domy, přičemž tyto podlahy byly objevovány i v několika horizontech nad sebou (Hladík a kol. 2015, 281-283).

Uvědomujeme si, že se Roztoky a Mikulčice nacházejí v oblastech s výrazně odlišnou geologickou minulostí (Český masiv a Karpatská soustava) a reprezentují různá období raného středověku. Avšak navzdory rozdílné geodiverzitě či klimatu, může složení lesní a křovinné vegetace v jejich okolí (Kuna a kol. 2013, 81-83; Látková 2017, 64) předznamenávat optimální stanovištní podmínky pro extenzivní chov prasat. Syntézy archeobotanických dat vypovídají o tom, že se zemědělský systém $\mathrm{v}$ raném středověku nadále řídil zemědělskými postupy používanými v období pravěku (Kuneš-Abraham 2017, 215). Z uvedeného důvodu uvažujeme o izotopovém signálu vzorků zubů prasat domácích z Roztok a Mikulčic jako o referenční značce pro zvolené soubory z Prahy.

\section{Analýza dat}

Dílčí výsledky archeozoologických i geochemických analýz jsou již součástí publikovaných (Kovačiková a kol. 2014; 2019; 2020) a připravované studie (Kovačiková a kol. 2020a). Vybraným nálezům zubů prasat domácích je společné, že z jejich kořenů byl extrahován kolagen v laboratoři Antropologického oddělení Národního muzea v Praze (dle Longin 1971; Bocherens 1992), a následné stanovení relativního zastoupení stabilních izotopů uhlíku a dusíku ve vzorcích kolagenu bylo provedeno metodou IRMS v laboratoři v Crewe (GB). V tomto př́ispěvku srovnáváme poměrná izotopová složení vzorků $(\delta)$ stanovená v laboratoři. Každá hodnota vyjadřuje, jak se izotopový poměr zkoumané látky liší od mezinárodně zavedeného standardu př́ślušného prvku (Květoň 2018, 30). Rozsahy hodnot pro jednotlivé lokality jsou uvedeny v tabulce 1 a pro znázornění jejich vzájemného vztahu, a to na základě podobnosti izotopových měření, byla využita hierarchická shluková analýza. Grafickými výstupy této metody, realizované užitím euklidovské vzdálenosti mezi shluky, jsou dva dendrogramy sestrojené pro každý stabilní izotop zvlášt' (obr. 2, 3). Za účelem statistického porovnání hodnot $\delta^{13} \mathrm{C}$ a $\delta^{15} \mathrm{~N}$ byla využita analýza rozptylu při jednoduchém třídění (ANOVA). Testování dat bylo uskutečněno na hladině významnosti $5 \%$ v programu Statistica 12.

\section{Komentované výsledky}

Hodnoty stabilních izotopů uhlíku $\left(\delta^{13} \mathrm{C}\right)$ a dusíku $\left(\delta^{15} \mathrm{~N}\right)$ spojené s osteologickými nálezy prasat domácích naznačují částečnou proměnlivost zdrojů krmiva již od raného středověku. Výsledek shlukové analýzy hodnot $\delta^{13} \mathrm{C}$ ukazuje, že se lokality sdružují do dvou skupin - 1) Praha a Mikulčice a 2) Roztoky (obr. 2). Uspořádání souborů dle hodnot $\delta^{15} \mathrm{~N}$ je poněkud jiné - 1) Praha a nedaleko od ní vzdálené Roztoky a 2) jihomoravské Mikulčice (obr. 3). Je evidentní, že pražské soubory jsou si nejbližší v případě obou izotopů.

Zůstaneme-li u raně středověkých sídlišst', pak se vzorky prasat z Malostranského náměstí v Praze (9.-11. století) a Roztok (6.-7. století) neliší v hodnotách obou stabilních izotopů ( $\mathrm{df}=4$; $\left.\delta^{13} \mathrm{C}: \mathrm{p}=0,450, \delta^{15} \mathrm{~N}: \mathrm{p}=0,963\right)$. Kosterní nálezy prasat zaujímají v těchto souborech výraznou většinu ve srovnání s ostatními hospodářskými druhy (Kuna a kol. 2013, 103; Kovačiková a kol. 2019, tab. 1 na s. 536). Na základě zastoupení věkových skupin prasat v Roztokách 


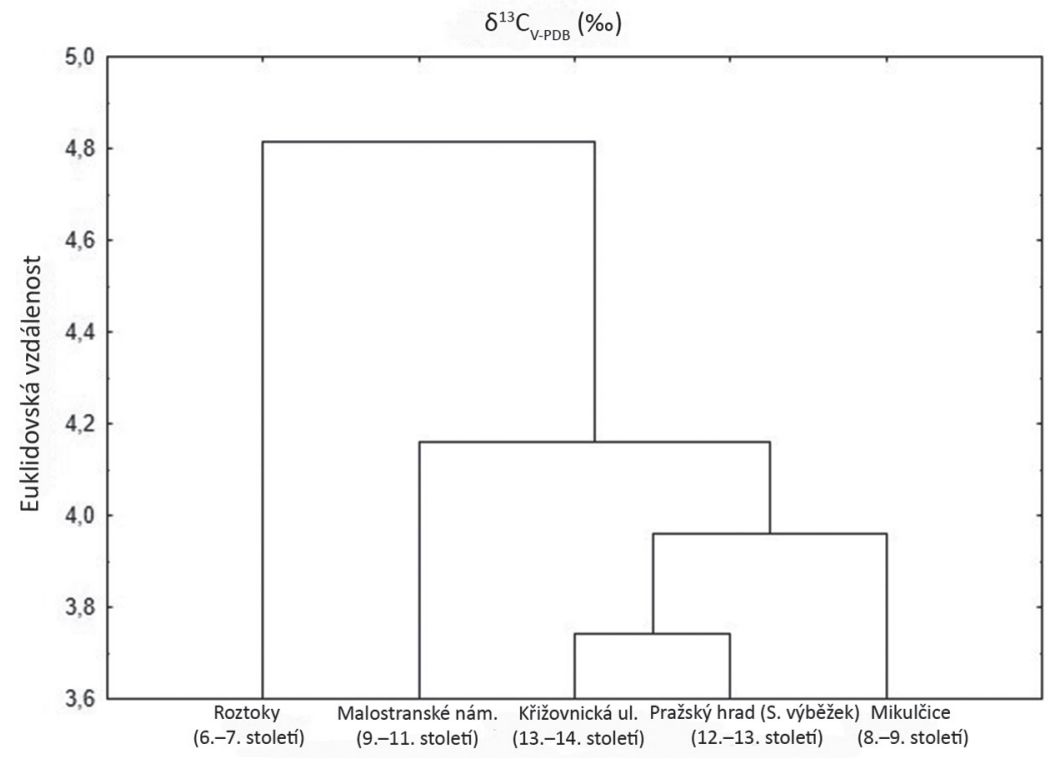

Obr. 2. Zobrazení výsledků shlukové analýzy hodnot $\delta^{13} \mathrm{C}$ naměřených ve vzorcích zubního kolagenu prasat domácích (Sus domesticus) na vybraných stř̌edověkých lokalitách.

Abb. 2. Darstellung der Ergebnisse der Clusteranalyse der an ausgewählten mittelalterlichen Fundstellen in Zahnkollagenproben von Hausschweinen (Sus domesticus) gemessenen $\delta^{13} \mathrm{C}$-Werte.

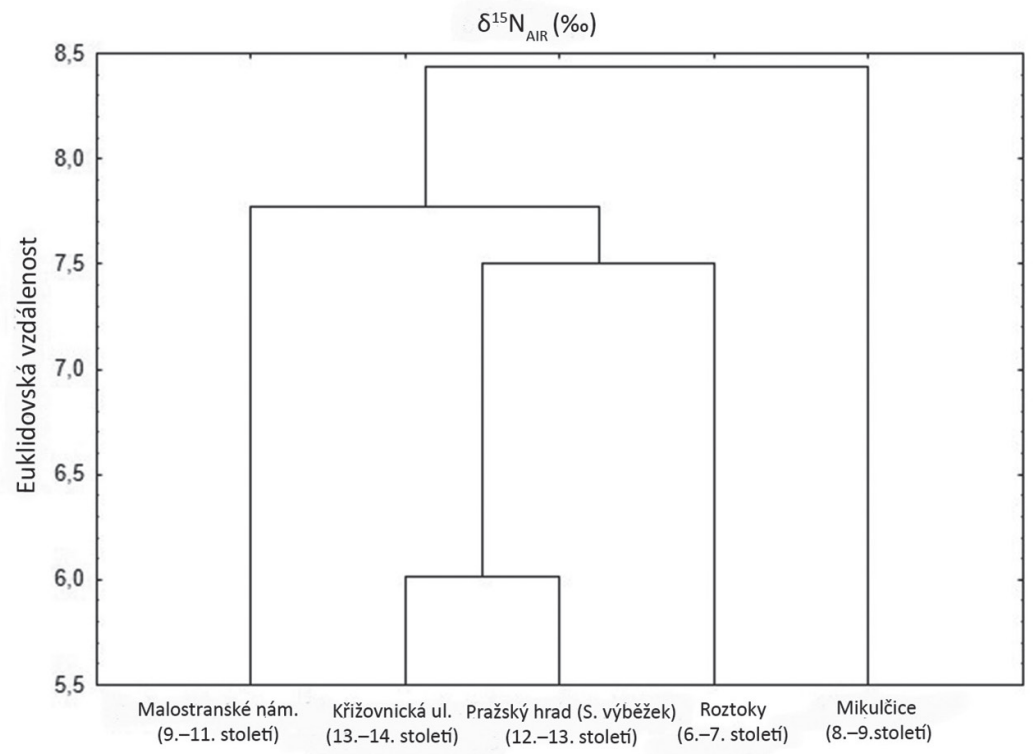

Obr. 3. Zobrazení výsledků shlukové analýzy hodnot $\delta^{15} \mathrm{~N}$ naměřených ve vzorcích zubního kolagenu prasat domácích (Sus domesticus) na vybraných středověkých lokalitách.

Abb. 3. Darstellung der Ergebnisse der Clusteranalyse der an ausgewählten mittelalterlichen Fundstellen in Zahnkollagenproben von Hausschweinen (Sus domesticus) gemessenen $\delta^{15} \mathrm{~N}$-Werte. 
předpokládáme, že ekonomika tamější společnosti byla samozásobitelská v produkci vepřového masa. Toto sdělení rovněž podporuje převaha evidovaných nálezů samic prasete ve vyšším věku, které byly zapojeny do obnovy stáda, oproti vyrovnanému rozložení pohlaví prasat v mladších věkových kategoriích (Kuna a kol. 2013, 104). Mladší soubor z Malostranského náměstí vykazuje podobné znaky. Z nich usuzujeme na určitou soběstačnost místního chovu, ačkoliv výraznější zastoupení samců může indikovat více ekonomických strategií (Kovačiková a kol. 2020a). Potrava většiny prasat v obou jmenovaných lokalitách nebyla výrazněji obohacena o ${ }^{15} \mathrm{~N}$ (obr. 4), proto nepředpokládáme, že by se zvířata volně pohybovala uvnitř sídlišt' a vyhledávala odpadky z domácností (Nardoto et al. 2006; Halley-Rosvold 2014). Č́stečnou oporu nachází toto tvrzení také ve shromážděných hodnotách téhož stabilního izotopu pro pražskou raně středověkou populaci (Kaupová a kol. 2018). Chov prasat v rámci raně středověkých sídelních areálů s podáváním převážně rostlinného krmiva nepovažujeme za příliš pravděpodobnou variantu. Požadavek na bílkoviny, které mají nezastupitelný vliv na zvětšování tělesné hmoty a neukládají se v těle do zásoby (Stupka a kol. 2009, 99), musel být pravděpodobně kryt z př́íjmu aktivně vyhledávané potravy ve venkovním prostředí, at' už se jednalo o celoroční volnou pastvu nebo vyhánění zvířat na pastvu v určité části roku (Price 2016, 81-91). Získané hodnoty $\delta^{13} \mathrm{C}$, které se u obou lokalit neliší (obr. 4), jsou charakteristické pro rostliny původem z oblasti mírného podnebného pásma $\left(\mathrm{C}_{3}\right.$ rostliny; Smith-Epstein 1971; Kohn 2010) a otevřené pastevní prostředí s minimálním zastíněním (Drucker et al. 2008), např́ílad pole, trvalé travní porosty nebo prosvětlené lesy. Pokles hodnot $\delta^{13} \mathrm{C}$ u vzorků z Roztok, které tuto lokalitu vydělují od zbylých nalezišt' (obr. 2), může přeci jen odrážet více zastíněný lesní podrost nebo vlhčí stanoviště (Somerville-Froehle-Schoeninger 2018, 93), kde prasata vyhledávala svou

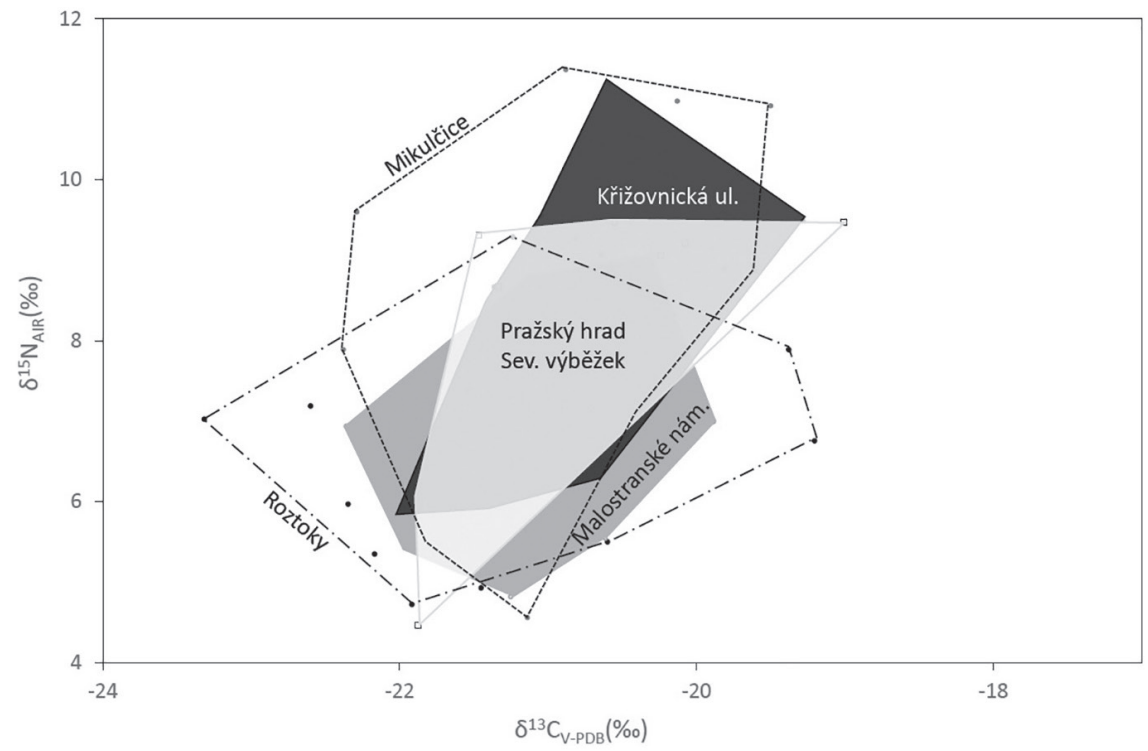

Obr. 4. Polygony hodnot $\delta^{13} \mathrm{C}$ a $\delta^{15} \mathrm{~N}$ naměřených ve vzorcích zubního kolagenu prasat domácích (Sus domesticus) ze středověkých lokalit v Praze. Pražský hrad - Severní výběžek, Praha - Křižovnická čp. 71/I a Malostranské náměstí podle Kovačiková a kol. 2020. Přerušovanou čárou jsou označeny referenční lokality Roztoky a Mikulčice. Roztoky podle Kovačiková nepublikovaná data; Mikulčice podle Kovačiková a kol. 2019a.

Abb. 4. Polygone der in Zahnkollagenproben von Hausschweinen (Sus domesticus) gemessenen $\delta^{13} \mathbf{C}$ - und $\delta^{15} \mathbf{N}-W e r t e$ von mittelalterlichen Fundstellen in Prag. Prager Burg - nördlicher Ausläufer, Prag - Kreuzherrenstr. Konskriptionsnr. 71/I und Kleinseitner Platz nach Kovačiková a kol. 2020. Mit gestrichelter Linie gekennzeichnet sind die Referenzfundstellen Roztoky und Mikulčice. Roztoky nach Kovačiková unveröffentlichte Daten; Mikulčice nach Kovačiková a kol. 2019 a. 
potravu. Antrakologická analýza spojená s časně slovanským obdobím definuje v Roztokách prrítomnost dubohabřin s podílem mezofilních křovin, slabé zastoupení vegetace lužního lesa nebo střídání lesního stanoviště s plochami s nízkým zapojením stromového patra. Zdejší stanovištní podmínky jsou navíc ovlivněny blízkostí Vltavy, která v lokalitě nastolovala vlhčí mikroklima (Kuna a kol. 2013, 79, 82). U minimálně o 200 let mladšího Malostranského náměstí dovozujeme, že jeho okolí nabízelo vhodné pastevní příležitosti. Přihlédneme-li k výsledkům archeobotanického výzkumu spojeného s osadou Nebovidy situovanou na úpatí kopce Petřína, v dosahu Malostranského náměstí, pak v 11. až na přelomu 12. a 13. století měla zdejší krajina částečně zemědělský ráz. Nepočetný soubor uhlíků zároveň poukazuje na přítomnost lokální kyselé doubravy s borovicí a břízou a v keřové formaci s lískou, přičemž relativně vysoký podíl borovice svědčí o člověkem podmíněných změnách, například lesní pastvě (Kočár-Kočárová 2013, 237, 239).

Detailní analýza rostlinných makrozbytků spojená s velkomoravskou sídelní aglomerací v Mikulčicích obklopenou říčními rameny řeky Moravy (9. století) prokázala existenci prosvětlených lesů na středně vlhkých půdách a v menší míře i lesů zastíněných. Ve stromovém a keřovém patře vlhčích lesních biotopů dominovaly dub nebo olše. Mimo stanoviště s vyšší hladinou podzemní a povrchové vody se v druhovém spektru objevují dřeviny rostoucí na živinami bohatých, zpravidla hlubokých půdách teplejších oblastí (Látková 2017, 64). Chov prasat domácích v Mikulčicích byl převážně extenzivní a jejich potrava měla podobné složení jako potrava prasat divokých, což vyplynulo z porovnání hodnot stabilních izotopů uhlíku a dusíku ve vzorcích obou forem (Kovačiková a kol. 2020). Přihlédneme-li pouze k hodnotám stabilního izotopu dusíku ve vzorcích prasat domácích a pokusíme-li se o širší porovnání hodnot téhož izotopu z mikulčického předhradí s Roztokami a Malostranským náměstím v Praze, pak se signifikantně odlišují ( $\mathrm{df}=4$; Mikulčice a Roztoky: $\mathrm{p}=0,018$, Mikulčice a Malostranské náměstí v Praze: $\mathrm{p}=0,091)$. Rozdíly mohou být způsobeny nejen odlišnou geografickou polohou těchto sídlišs' (jižní Morava a střední Čechy), ale i klimatickými podmínkami. Obohacení vzorků zubního kolagenu některých prasat $\mathrm{z}$ Mikulčic o ${ }^{15} \mathrm{~N}$ (obr. 4) může svědčit také o volbě jiné chovatelské strategie či kombinaci více přístupů. Některá mikulčická prasata, jejichž hodnoty $\delta^{15} \mathrm{~N}$ se blíží hodnotám naměřeným ve vzorcích lidské populace (Kovačiková a kol. 2020), mohla být více kontrolována chovatelem a přikrmována například zbytky z domácností nebo ze zemědělské činnosti (Balasse et al. 2018, 83).

Sílící populační růst ve vrcholném středověku se projevil větším tlakem na úrodu. Na orné půdě se střídaly jařiny s ozimy a spolu s úhorem dávaly vznik trojpolnímu systému hospodaření (Kuneš-Abraham 2017, 215). Pastviny s roztroušenými stromy, které spoluutvářely ráz středověké krajiny, představovaly mozaiku otevřeného lesa s jednokmennými stromy a travnatých ploch a sloužily $\mathrm{k}$ mnoha účelům od sběru plodů přes obstarávání palivového dřeva po vyhledávání žaludů prasaty (Chytrý 2017, 251). Změny ve středověké krajině, která se mezi 12. až 14. stoletím ocitla pod silným kolonizačním tlakem (Klápště 2005, 170-181), se v palynologických datech projevují např́iklad snižováním diverzity botanických druhů (Kozáková a kol. 2009, 486).

V mladších souborech z Prahy - Pražského hradu - Severního výběžku (12.-13. století) a Kř́ižovnické ulice na Starém Městě pražském (13.-14. století) přibývají vzorky s vyššími hodnotami $\delta^{15} \mathrm{~N}$ a $\delta^{13} \mathrm{C}$ (obr. 4) a roste variační rozpětí obou izotopů, což může značit větší rozmanitost přijímaného krmiva, případně diverzifikaci chovatelských strategií (Kovačiková a kol. 2020a). Statistické výpočty neindikují rozdíly mezi nalezišti $\left(\mathrm{df}=4 ; \delta^{13} \mathrm{C}: \mathrm{p}=0,999\right.$, $\left.\delta^{15} \mathrm{~N}: \mathrm{p}=0,999\right)$ a analýza pomocí hierarchické shlukové analýzy poukazuje na jejich vzájemnou podobnost (obr. 2, 3).

Při stanovení trofické úrovně prasat domácích se setkáváme se snahou vymezit hranici pro př́ijem krmiva s vyšším obsahem proteinu. Takto uměle vytvořený předěl využívají někteří badatelé pro lepší interpretaci alimentárních a nealimentárních vlivů ovlivňujících efektivitu výživy prasat. Pro hodnoty $\delta^{15} \mathrm{~N}$ bývá udávána mez $8 \%$ (R. Madgwick, ústní sdělení) nebo 9 \% (Frémondeau et al. 2017, obr. 8 na s. 45, 48-49). V uvedených datových souborech hranici 
8 \% překračuje 43 \% zvířat z lokality Pražský hrad a 52 \% z Kř́žžovnické ulice (Kovačiková a kol. 2020). V důsledku vyššího prŕíjmu živočišných bílkovin, například ve formě odpadu z domácností, dochází k obohacování vzorků kolagenu o těžký izotop dusíku. Tuto interpretaci podporuje i posun hodnot $\delta^{13} \mathrm{C}$ (Bocherens-Drucker 2003). Vedle vyššího př́ijmu živočišných bílkovin se mohl v potravě prasat projevit také rostoucí obsah dusíku ve střredověkých půdách, např́iklad v důsledku hnojení (Fraser et al. 2011; Bogaard et al. 2007). Prasata mohla být záměrně vyháněna na zemědělské plochy, které ležely ladem, kde rytím a svými výkaly přispívala ke kultivaci těchto ploch (Hamilton-Thomas 2012, 252). Ve srovnání s raně středověkými lokalitami ukazují výsledky archeozoologických analýz mladších souborů na určitý úbytek kostí a zubů prasat (Kovačiková a kol. 2019), přičemž tento trend je výraznější v lokalitě Křižovnická čp. 71/I než v lokalitě Pražský hrad - Severní výběžek. Oba sledované pražské soubory se vyznačují častější porážkou prasat mezi 18 až 24 měsíci, zároveň se v nich ale objevují i kosterní pozůstatky jedinců, kteří byli zabiti po druhém roce života (Kovačiková a kol. 2019). Orientace na více zdrojů živin mohla mít vliv na vyšší efektivitu výkrmu, resp. produkci vepřového masa a tuku. Širší intervaly hodnot obou izotopů mohou být rovněž důsledkem skutečnosti, že v souborech se vedle zvířat chovaných ve větší blízkosti lidských sídel, at' už v samotném městě či na vesnicích, mohou častěji vyskytovat i jedinci s odlišnou pastevní historií, kteři se dostávali do města např́íklad prostřednictvím trhu.

\section{Závěr}

Předkládaná studie se zaměřuje na management chovu prasete domácího v období stř̌edověku. Výsledky analýzy stabilních izotopů vybraných souborů ukazují, že v období raného středověku převažoval extenzivní způsob chovu prasat. Vyšší poptávka po mase (a tuku) těchto zvířat, kterou odvozujeme z početných nálezů jejich kostí a zubů na zkoumaných lokalitách, pravděpodobně neměla vliv na intenzifikaci jejich chovu. Krajina raně středověkých Čech patrně poskytovala dostatek potravních př́ležitostí pro uživení stád prasat. Menší počet jedinců v mikulčickém souboru s vyššími hodnotami $\delta^{15} \mathrm{~N}$ se pravděpodobně zdržoval v těsnější blízkosti lidských sídel, popřípadě byl dokrmován zbytky z domácností. Soubory hodnot stabilních izotopů z mladšího středověku vykazují ve srovnání s hodnotami z raně středověkého Malostranského náměstí nejen vyšší variační rozpětí, ale jsou také obohacenější o ${ }^{15} \mathrm{~N}$. Z toho lze usuzovat, že vedle stále převažujícího extenzivního chovu prasat byl praktikován také intenzivnější a více kontrolovaný způsob chovu těchto zvířat. Na stávající závěry by bylo dobré v budoucnu navázat dalšími analýzami, nebot' si uvědomujeme, že výsledky mohou být ovlivněny výběrem souborů, počtem získaných měření či dalšími faktory.

Tento publikační výstup vznikl za podpory projektu Zvířata ve středověké Praze: archeozoologický výzkum a analýza stabilních izotopů (GAUK č. 208217) a projektu Zviŕrata ve středověkém městě. Archeozoologie a analýza stabilních izotopů (GAČR 18-10003S). Měření izotopového složení referenčních vzorků z Mikulčic a Roztok bylo financováno z prostředků projektu GAČR 17-01878S a projektu NEXLIZ CZ.1.07/2.3.00/30.0038.

\section{Literatura}

ALBARELLA, U., 2004: Meat production and consumption in town and country. In: Town and country in the middle ages: contrasts, contacts and interconnections 1100-1500 (Giles, K.-Dyer, C., edd.), 131-148. Leeds.

- 2006: Pig husbandry and pork consumption in medieval England. In: Food in Medieval England, Diet and Nutrition (Woolgar, C. M.-Serjeantson, D.-Waldron, T., edd.), 72-87. Oxford. 
ALBARELLA, U. et al., 2007: Albarella, U.-Manconi, F.-Vigne, J. D.-Rowley-Conwy, P., Ethnoarchaeology of pig husbandry in Sardinia and Corsica. In: Pigs and humans. 10,000 years of interaction (Albarella, U.-Dobney, K.-Ervynck, A.-Rowley-Conwy, P., edd.), 285-307. Oxford.

ASHBY, S. P., 2002: The role of zooarchaeology in the interpretation of socioeconomic status: a discussion with reference to Medieval Europe, Archaeological Review from Cambridge 18, 37-59.

BALASSE, M. et al., 2018: Balasse, M.-Cucchi, T.-Evin, A.-Bălăşescu, A.- Frémondeau, D.-Horard-Herbin, M. P., Wild game or farm animal? Tracking human-pig relationships in ancient times through stable isotope analysis. In: Hybrid Communities Biosocial Approaches to Domestication and Other Trans-species Relationships (Stépanoff, C.-Vigne, J.-D., edd.), 81-96. Abingdon - New York.

BALOGHOVÁ, R., 2010: Archeozoologie tř́i vrcholně středověkých městských parcel v Chrudimi - Hradební ulici. Nepubl. diplomová práce, Katedra zoologie, PřF JU, České Budějovice.

BLÁHA, J., 2000: Archeologické a archeozoologické poznámky ke stravování olomouckých Slovanů v předvelkomoravském období (konec 7. a počátek 9. stol.), Střední Morava 10, 66-73.

- 2000a: Několik úvodních poznatků a reflexí k jídelníčku olomouckých Slovanů v období Velké Moravy, Střední Morava 11, 103-109.

BLAIR, R., 2007: Nutrition and feeding of organic pigs. Trowbridge.

BOCHERENS, H., 1992: Biogéochimie isotopique $\left({ }^{13} \mathrm{C},{ }^{15} \mathrm{~N},{ }^{18} \mathrm{O}\right)$ et paléontologie des vertébrés: applications à l'étude des réseaux trophiques révolus et des paléoenvironnements. Nepubl. disertační práce, Université Paris IV, Paris

BOCHERENS, H.-DRUCKER, D., 2003: Trophic level isotopic enrichment of carbon and nitrogen in bone collagen: case studies from recent and ancient terrestrial ecosystems, International Journal of osteoarchaeology 13, 46-53. https://doi.org/10.1002/oa.662

BOGAARD, A. et al., 2007: Bogaard, A.-Heaton, T. H.-Poulton, P.-Merbach, I., The impact of manuring on nitrogen isotope ratios in cereals: archaeological implications for reconstruction of diet and crop management practices, Journal of Archaeological Science 34, 335-343. https://doi.org/10.1016/j.jas.2006.04.009

BOHÁČOVÁ, I. a kol., 1990: Boháčová, I.-Frolík, J.-Petříčková, J.-Žeglitz, J., Příspěvek k poznání života a životního prostředí na Pražském hradě a Hradčanech - Ein Beitrag zur Kenntnis des Lebens und der Umwelt auf der Prager Burg und in Hradčany, AH 15, 177-189.

CRABTREE, P. J., 2010: Agricultural innovation and socio-economic change in early medieval Europe: evidence from Britain and France, World Archaeology 42, 122-136. https://oi.org/10.1080/00438240903430373

ČIHÁKOVÁ, J., 2017: Rotunda sv. Václava. In: Průvodce pražskou archeologií (Boháčová, I.-Podliska, J., edd.), 90-91. Praha.

- 2017a: Vzpomínka na Ladislava Hrdličku v kontextu komplikovaných sídelních stratigrafií na pražské Malé Straně. In: Forum Urbes Medii Aevi 10/2 (Klápště, J., ed.), 232-239. Brno - Praha.

- 2018: The Lesser Town of Prague in the Tenth and Eleventh Centuries. In: Moravian and Silesian Strongholds of the Tenth and Eleventh Centuries in the Context of Central Europe, Spisy Archeologického ústavu AV ČR Brno 57 (Kouřil, P.-Procházka, R., edd.), 283-303. Brno.

ČIHÁKOVÁ, J.-MÜLLER, M., 2006: Zpráva o nálezu rotundy sv. Václava na Malostranském náměstí v Praze, ZPP 66, 100-116.

DENIRO, M. J., 1987: Stable isotopy and archaeology, American Scientist 75, 182-191.

DENIRO, M. J.-EPSTEIN, S., 1981: Influence of diet on the distribution of nitrogen isotopes in animals, Geochimica et cosmochimica acta 45, 341-351. https://oi.org/10.1016/0016-7037(81)90244-1

DRESLEROVÁ, G., 2018: Sociální a ekonomická stratifikace velkomoravského centra na základě archeozoologických analýz. Nepubl. disertační práce, ÚAM FF MU, Brno.

DRUCKER, D. G. et al., 2008: Drucker, D. G.-Bridault, A.-Hobson, K. A.-Szuma, E.-Bocherens, H., Can carbon-13 in large herbivores reflect the canopy effect in temperate and boreal ecosystems? Evidence from modern and ancient ungulates, Palaeogeography, Palaeoclimatology, Palaeoecology 266, 69-82. https://doi.org/10.1016/j.palaeo.2008.03.020

DVOŘÁKOVÁ, J., 2015: Zvieratá v miestach. In: Dvořáková, D. a kol., Človek a svet zvierat v stredoveku, 461-465. Bratislava.

FRASER, R. A. et al., 2011: Fraser, R. A.-Bogaard, A.-Heaton, T.-Charles, M.--Jones, G.-Christensen, B. T.Halstead, P.-Merbach, I.-Poulton, P. R.-Sparkes, D.-Styring, A. K., Manuring and stable nitrogen isotope 
ratios in cereals and pulses: towards a new archaeobotanical approach to the inference of land use and dietary practices, Journal of Archaeological Science 38, 2790-2804. https://doi.org/10.1016/j.jas.2011.06.024

FRÉMONDEAU, D. et al., 2017: Frémondeau, D.-De Cupere, B.-Evin, A.-Van Neer, W., Diversity in pig husbandry from the Classical-Hellenistic to the Byzantine periods: An integrated dental analysis of Düzen Tepe and Sagalassos assemblages (Turkey), Journal of Archaeological Science: Reports 11, 38-52. https://doi.org/10.1016/j.jasrep.2016.11.030

FROLÍK, J., 1997: Archeologický výzkum v tzv. Severním výběžku na Pražském hradě. Příspěvek k počátkům osídlení západního předhradí Pražského hradu - Die Ausgrabung in sog. Nordausläfer der Prager Burg. Ein Beitrag zu den Anfängen der Besiedlung des westlichen Vorfelds der Prager Burg, Archaeologica Pragensia 13, 75-92.

- 2017: Pohřebiště u kostela P. Marie a na II. nádvoří Pražského hradu. Díl II. Analýza - The Cemetery in the Second Courtyard and by the Church of the Virgin Mary at Prague Castle: Part II. Analysis. Projekt ABG 1. Castrum Pragense 14/2. Praha.

GRANT, A., 2002: Food, status and social hierarchy. In: Consuming passions and patterns of consumption (Miracle, P.-Milner, N., edd.), 17-23. Cambridge.

HADJIKOUMIS, A., 2012: Traditional pig herding practices in southwest Iberia: Questions of scale and zooarchaeological implications, Journal of Anthropological Archaeology 31, 353-364. https://doi.org/10.1016/j.jaa.2012.02.002

HAJNALOVÁ, E., 1999: Archeobotanika pěstovaných rostlin. Učebné texty pre dištančné štúdium - Archaeobotany of crops. The college textbook. Nitra.

HALLEY, D. J.-ROSVOLD, J., 2014: Stable isotope analysis and variation in medieval domestic pig husbandry practices in northwest Europe: absence of evidence for a purely herbivorous diet, Journal of archaeological science 49, 1-5. https://doi.org/10.1016/j.jas.2014.04.006

HALSTEAD, P.-ISAAKIDOU, V., 2011: A pig fed by hand is worth two in the bush: Ethnoarchaeology of pig husbandry in Greece and its archaeological implications. In: Ethnozooarchaeology: The Present and Past of Human-Animal Relations (Albarella, U.-Trentacoste, A., edd.), 160-174. Oxford.

HAMILTON, J.-THOMAS, R., 2012: Pannage, pulses and pigs: isotopic and zooarchaeological evidence for changing pig management practises in later Medieval England, Medieval Archaeology 56, 234-259. https://doi.org/10.1179/0076609712Z.0000000008

HAMMOND, C.-O'CONNOR, T., 2013: Pig diet in medieval York: carbon and nitrogen stable isotopes, Archaeological and Anthropological Sciences 5, 123-127. https://oi.org/10.1007/s12520-013-0123-x

HAUSTEINOVÁ, T., 2015: Archeozoologie jihočeského přemyslovského hradiště Na Jánu v Netolicích. Nepubl. bakalářská práce, Katedra zoologie, PřF JU, České Budějovice.

HAVRDA, J. a kol., 2017: Havrda, J.-Kočár, P.-Kočárová, R.-Kozáková, R.-Podliska, J.-Sůvová, Z., K vývoji a podobě historického nadloží Staroměstského náměstí v Praze Příspěvek k mezioborovému výzkumu veřejných prostranství - On the Development and Situation of the Historic Overburden of Old Town Square in Prague, A Contribution to Interdisciplinary Research of Public Space. In: Forum Urbes Medii Aevi 10/2 (Klápště, J., ed.), 164-195. Brno - Praha.

HEDGES, J. E.-STEVENS, R. E.-KOCH, P. L., 2006: Isotopes in bones and teeth. In: Isotopes in Palaeoenvironmental Research, volume 10 (Leng, M. J., ed.), 117-145. Dordrecht.

HLADÍK, M., 2014: Hospodárske zázemie Mikulčíc. Sídelná štruktúra na strednom toku rieky Morava v 9.-1. polovici 13. storočia. Brno.

HLADÍK, M. a kol., 2015: Hladík, M.-Kalčík, L.-Mazuch, M.-Poláček, L.-Škojec, J., Mikulčice (okr. Hodonín). Terénní výzkumy hradiště „Valy“v roce 2014, PV 56, 281-283.

HURAJČÍKOVÁ, V., 2014: Příspěvek k počátkům Pražského hradu (doklady a proměny osídlení západního předhradí na místě tzv. Severního výběžku). Nepubl. diplomová práce, Ústav pro archeologii, FF UK, Praha.

CHRZANOWSKA, W.-JANUSZKIEWICZ-ZAŁĘCKA, D., 2003: Tierknochenfunde aus der Vor- und Hauptburg des Burgwalls von Mikulčice. In: Studien zum Burgwall von Mikulčice. Band 5 (Poláček, L., ed.), 121-138. Brno.

CHYTRÝ, M., 2017: Current Vegetation of the Czech Republic. In: Chytrý, M.-Danihelka, J.-Kaplan, Z.Pyšek, P., Flora and vegetation of the Czech Republic. Plant and vegetation 14, 229-337. Cham. 
IWASZCZUK, U., 2014: Animal husbandry on the Polish territory in the Early Middle Ages, Quaternary international 346, 69-101.

JØRGENSEN, D., 2013: Running amuck? Urban swine management in late medieval England, Agricultural History 87, 429-451. https://doi.org/10.3098/ah.2013.87.4.429

KAUPOVÁ, S. a kol., 2018: Kaupová, S.-Velemínský, P.-Stránská, P.-Bravermanová, M.-Frolíková, D.Tomková, K.-Frolík, J., Dukes, elites, and commoners: dietary reconstruction of the early medieval population of Bohemia (9th-11th Century AD, Czech Republic), Archaeological and Anthropological Sciences 11, 1887-1909.

KLÁPŠTĚ, J., 2005: Proměna českých zemí ve středověku. Praha.

KOČÁR, P.-KOČÁROVÁ, R., 2013: Flóra a vegetace Nebovid. In: Nebovidy. Středověká osada v pražském podhradí. Archeologické prameny k dějinám Prahy, sv. 6 (Havrda, J.-Tryml, M., edd.), $223-241$. Praha.

KOHN, M. J., 2010: Carbon isotope compositions of terrestrial C3 plants as indicators of (paleo) ecology and (paleo) climate, Proceedings of the National Academy of Sciences 107, 19691-19695.

KOVAČIKOVÁ, L. a kol., 2014: Kovačiková, L.-Kyselý, R.-Trojánková, O., Determinace osteologického materiálu z výzkumu v tzv. Severním výběžku Pražského hradu, č. j. 3926/14. Osteologický posudek ulož. v archivu nálezových zpráv ARÚ AV ČR v Praze.

KOVAČIKOVÁ, L. a kol., 2019: Kovačiková, L.-Trojánková, O.-Meduna, P.-Starec, P.-Burian, M.-Čiháková, J.-Frolík, J., Trendy v konzumaci masa a dalších živočišných produktů ve středověké Praze - Trends in the consumption of meat and other animal products in medieval Prague, AR LXXI, 529-552.

KOVAČIKOVÁ, L. a kol., 2020: Kovačiková, L.-Drtikolová Kaupová, S.-Poláček, L.-Velemínský, P.-Limburský, P.-Brůžek, J., Pig-breeding management in the Early Medieval stronghold at Mikulčice (8th-9th century, Czech Republic), Environmental Archaeology. https://doi.org/10.1080/14614103.2020.1782583

KOVAČIKOVÁ, L. a kol., 2020a, v tisku:: Kovačiková, L.-Trojánková, O.-Limburský, P.-Starec, P.-Meduna, P., Livestock as an indicator of socioeconomic changes in Medieval Prague, Archaeological and Anthropological Sciences.

KOZÁKOVÁ, R. a kol., 2009: Kozáková, R.-Pokorný, P.-Havrda, J.-Jankovská, V., The potential of pollen analyses from urban deposits: multivariate statistical analysis of a data set from the medieval city of Prague, Czech Republic, Vegetation History and Archaeobotany 18, 477-488. https://doi.org/10.1007/s00334-009-0217-7

KRATOCHVÍL, Z., 1978: Übersicht des Tierknochenmateriales von den Grabungen auf dem Burgwall in Mikulčice aus den Jahren 1954-1967 (Bez. Hodonín), PV 1976, 54-58.

KUNA, M. a kol., 2013: Kuna, M.-Hajnalová, M.-Kovačiková, L.-Lisá, L.-Novák, J.-Bureš, M.-Cílek, V.-Hošek, J.-Kočár, P.-Majer, A.-Makowiecki, D.-Cummings, L. S.-Sůvová, Z.-Světlík, I.-Vandenberghe, D.-Nieuland, J. V.-Yost, C. L.-Zabilska-Kunek, M., Raně středověký areál v Roztokách z pohledu ekofaktů - The Early Medieval site at Roztoky. The evidence of ecofacts, PA CIV, 59-147.

KUNEŠ, P.-ABRAHAM, V., 2017: History of Czech Vegetation Since the Late Pleistocene. In: Chytrý, M.Danihelka, J.-Kaplan, Z.-Pyšek, P., Flora and vegetation of the Czech Republic. Plant and vegetation 14, 193-227. Cham. https://doi.org/10.1007/978-3-319-63181-3_6

KVĚTOŇ, J., 2018: Stabilní izotopy - terminologie, analýzy, př́irodní výskyt. In: Šantrůček, J.-Šantrůčková, H. a kol., Stabilní izotopy biogenních prvků. Použití v biologii a ekologii, 21-34. Praha.

KYSELÝ, R., 2003: Savci (Mammalia) z raně středověkého hradu Stará Boleslav (střední Čechy) - Mammals From The Early Medieval Stronghold Stará Boleslav (Central Bohemia), Mediaevalia archaeologica 5, 311-334.

-2015: Archeozoologická analýza raně středověkých kostí - An archaeozoological analysis of early medieval bones. In: Vyšehrad - knížecí a královská akropole. Svědectví archeologie (Moucha, V.-Nechvátal, B.Varadzin, L., edd.), 421-528. Praha.

LÁTKOVÁ, M., 2017: The archaeobotany of Mikulčice. Food supply to the early medieval stronghold. Studien zum Burgwall von Mikulčice. Band XI. Spisy archeologického ústavu AV ČR Brno 55 (Poláček L.Kouřil P., edd.). Brno.

LEGUAY, J. P., 1999: La pollution au Moyen Age. Paris. 
LONGIN, R., 1971: New method of collagen extraction for radiocarbon dating, Nature 230, $241-242$. https://doi.org/10.1038/230241a0

MIKLOVÁ, V., 2019: Odpadní objekty ve vrcholně středověkých a novověkých městech ve vztahu k archeozoologickým nálezům. Nepubl. diplomová práce, Archeologický ústav, FF JU, České Budějovice.

MLÍKOVSKÝ, J., 2003: Zvířata a jejich role na raně středověkém hradě Stará Boleslav (střední Čechy) Animals and their role in the Early Medieval Stronghold Stará Boleslav (Central Bohemia), Mediaevalia archaeologica 5, 347-365.

NARDOTO, G. B. et al., 2006: Nardoto, G. B.-De Godoy, P. B.-Ferraz, E. S. D. B.-Ometto, J. P. H. B.-Martinelli, L. A., Stable carbon and nitrogen isotopic fractionation between diet and swine tissues. Scientia Agricola 63, 579-582. https://doi.org/10.1590/S0103-90162006000600012

O'CONNOR, T., 2010: Livestock and deadstock in early medieval Europe from the North Sea to the Baltic, Environmental Archaeology 15, 1-15. https://doi.org/10.1179/146141010X12640787648612

O’LEARY,M.H., 1988:Carbonisotopesinphotosynthesis,Bioscience 38,328-336.https://doi.org/10.2307/1310735

PARDO, L. H.-NADELHOFFER, K. J., 2010: Using nitrogen isotope ratios to assess terrestrial ecosystems at regional and global scales. In: Isoscapes. Understanding Movement, Pattern, and Process on Earth Through Isotope Mapping (West, J. B.-Bowen, G. J.-Dawson, T. E.-Tu, K. P., edd.), 221-249. Dordrecht.

PEŠKE, L., 1985: Domácí a lovná zvířata podle nálezů na slovanských lokalitách v Čechách, SbNM A XXXIX, 209-216.

PETŘÍČKOVÁ, J., 2002: Analýza osteologického materiálu. In: Archeologie středověkého domu v Mostě (čp. 226) - The Archaeology of a medieval House (No. 226) in Most. Mediaevalia Archaeologica 4 (Klápště, J., ed.), 167-180. Praha - Most.

PILAAR BIRCH, S. E., 2013: Stable isotopes in zooarchaeology: an introduction, Archaeological and Anthropological Sciences 5, 81-83. https://doi.org/10.1007/s12520-013-0126-7

POLÁČEK, L., 2016: Hradiště Mikulčice - Valy a Velká Morava. Mikulčice - průvodce svazek II. Brno.

PRICE, M., 2016: Pigs and Power: Pig Husbandry in Northern Mesopotamia During the Emergence of Social Complexity (6500-2000 Bc), Doctoral dissertation, Department of Anthropology, Graduate School of Arts and Sciences, Harvard University. Cambridge.

SIRIGNANO, C. et al., 2014: Sirignano, C.-Sologestoa, I. G.-Ricci, P.-García-Collado, M. I.-Altieri, S.Castillo, J. A. Q.-Lubritto, C., Animal husbandry during Early and High Middle Ages in the Basque Country (Spain), Quaternary International 346, 138-148. https://doi.org/10.1016/j.quaint.2014.05.042

SMITH, B. N.-EPSTEIN, S., 1971: Two categories of 13C/12C ratios for higher plants, Plant physiology 47 , 380-384. https://doi.org/10.1104/pp.47.3.380

SOMERVILLE, A. D.-FROEHLE, A. W.-SCHOENINGER, M. J., 2018: Environmental influences on rabbit and hare bone isotope abundances: Implications for paleoenvironmental research. Palaeogeography, palaeoclimatology, palaeoecology 497, 91-104.

STAREC, P., 2017: Praha 1 - Josefov, Pařížská ulice čp. 205/V. In: Dragoun Z. a kol., Archeologický výzkum v Praze v letech 2015-2016, Pražský sborník historický 45, 615.

- 2017a: Praha 1 - Staré Město, Křižovnická ulice čp. 71/I. In: Dragoun Z. a kol., Archeologický výzkum v Praze v letech 2015-2016, Pražský sborník historický 45, 635.

STUPKA, R.-ŠPRYSL, M.-ČÍTEK, J., 2009: Základy chovu prasat. Praha.

ŠAMATA, J.-KOVAČIKOVÁ, L.-KYSELÝ, R., 2001: Archeologické výzkumy v historickém jádru města Chebu. Archeologické výzkumy v Čechách 2000, Zprávy České archeologické společnosti - Supplément 45, 12.

ŠARAPATKA, B.-URBAN, J. a kol., 2006: Ekologické zemědělství v praxi. Šumperk.

ŠEDIVÝ, J., 2015: Zvieratá v stredovekom meste na príklade Bratislavy. In: Dvořáková, D. a kol., Človek a svet zvierat v stredoveku, 466-489. Bratislava.

ŠIMEK, M.-HYNŠT, J., 2019: Anorganické živiny a jejich transformace. In: Šimek, M. a kol., Živá půda. Ekologie, využívání a degradace půdy 2, 543-618. Praha.

ZANGRANDO, A. F. et al., 2014: Zangrando, A. F.-Tessone, A.-Ugan, A.-Gutiérrez, M. A., Applications of stable isotope analysis in zooarchaeology: an introduction, International Journal of Osteoarchaeology 24, 127-133. https://doi.org/10.1002/oa.2378 


\section{Zusammenfassung}

\section{Schweinehaltung im Mittelalter im Prisma stabiler Kohlenstoff- und Stickstoffisotopen}

In Anknüpfung an in verschiedenen Teilen Prags durchgeführte archäologische Grabungen kommen immer mehr archäozoologische Studien hinzu, die eine Auswertung osteologischer Funde aus der Zeit des Früh- und Hochmittelalters enthalten. Zu ihren Hauptoutputs zählen die Beobachtung der Repräsentativität von Knochenfunden der einzelnen Tierarten, Schätzungen zur Bedeutung tierischer Produkte in der Verpflegung der Einwohner Prags oder die Beschreibung von Tierknochenfunden, die als Rohstoffe für die Handwerksproduktion Verwendung fanden oder zu Gegenständen des Alltagsbedarfs hergerichtet wurden. Bislang nur sehr wenige Informationen betreffen die Bedingungen der Haltung von Wirtschaftstieren in größeren Siedlungsagglomerationen und Fütterungstechniken, was eng mit der Effektivität der Produktion von tierischen Erzeugnissen verbunden ist. Zur Klärung dieses Themas erweist sich die Verknüpfung eines archäozoologischen Ansatzes mit einer Analyse der auf die Ernährung hinweisenden stabilen Kohlenstoff- und Stickstoffisotopen als geeignet. Unabdingbare Voraussetzung für die Erlangung relevanter Resultate einer Isotopenanalyse ist jedoch eine durchdachte Auswahl osteologischer Funde zwecks Probenentnahme und eine ausreichende Repräsentativität dieser Funde. In der vorliegenden Studie waren wir bestrebt, eine Datenserie aus drei Prager Komplexen zu vergleichen, wobei wir uns auf eine der bedeutendsten Wirtschaftstierarten des Mittelalters - das Hausschwein (Sus domesticus) - konzentriert haben. Bei der Wahl der Fundstellen figurieren absichtlich solche Komplexe, die verschiedene Zeiträume und Orte repräsentieren. Um das Fütterungsverfahren von mit Prag verbundenen Schweinen besser zu definieren und ein Modell ihrer jeweiligen Haltung in unterschiedlichen Zeiträumen und unter verschiedenen sozialen Bedingungen verdeutlichen zu können, haben wir Isotopenreferenzmessungen herangezogen, die für frühmittelalterliche Siedlungen eines jeweils unterschiedlichen Typs zusammengetragen wurden. Die Schlussfolgerungen, zu denen wir durch den Vergleich der Fundstellen gekommen sind, haben gezeigt, dass es mehrere Arten der Schweinehaltung gegeben hat, die sich untereinander vermischt haben und es unter dem Druck verschiedener Umstände, wie beispielsweise Veränderungen in der Landschaft oder einem quantitativen Wachstum der Stadtbevölkerung, zu ihrer Modifizierung kam. Aus zeitlicher Sicht nehmen wir am Beispiel der Prager Fundstellen eine gewisse Verlagerung von einer - auch in keinem Widerspruch zu den archäobotanischen Schlussfolgerungen stehenden überwiegend extensiven (ländlichen) Schweinehaltung in der Zeit des frühen Mittelalters hin zu einem Anstieg der Anzahl von mehr unter menschlicher Kontrolle gehaltenen Tieren im Hochmittelalter wahr. Es ist gut, die von den geochemischen Analysen ebenfalls bestätigte Variabilität von Isotopenmessungen, bei denen es sich oftmals um eine Verschiebung der $\delta^{15 \mathrm{~N}_{-}}$ Werte um mindestens ein Trophieniveau handelt, besonders bei der Zusammenstellung des Isotopenhintergrundes zu berücksichtigen.

Der vorliegende Publikationsoutput entstand unter Förderung des Forschungsprojektes Tiere im mittelalterlichen Prag: archäologische Forschung und Analyse stabiler Isotopen (GAUK Nr. 208217) und des Forschungsprojektes Tiere in der Stadt des Mittelalters. Archäozoologie und Analyse stabiler Isotopen (GAČR 18-10003S). Die Messungen der Isotopenzusammensetzung der Referenzproben aus Mikulčice und Roztoky wurden aus Mitteln des Projektes GAČR 17-01878S und des Projektes NEXLIZ CZ.1.07/2.3.00/30.0038 finanziert.

Mgr. Olga Trojánková, Ústav pro archeologii Filozofické fakulty Univerzity Karlovy, Celetná 20, 11642 Praha; Laboratoř archeobotaniky a paleoekologie Přírodovědecké fakulty Jihočeské univerzity, Na Zlaté stoce 3, 37005 České Budějovice, Česká republika, otrojankova@gmail.com 
Ing. Lenka Kovačiková, Ph.D., Laboratoř archeobotaniky a paleoekologie Př́rodovědecké fakulty Jihočeské univerzity, Na Zlaté stoce 3, 37005 České Budějovice; Ústav pro archeologii Filozofické fakulty Univerzity Karlovy, Celetná 20, 11642 Praha, Česká republika, lenka.kovacikova@gmail.com

PhDr. Jan Frolík, CSc., Archeologický ústav AV ČR, v. v. i., Letenská 4, 11801 Praha, Česká republika, frolik@arup.cas.cz

Mgr. Petr Starec, Muzeum hlavního města Prahy, Kožná 1, 11001 Praha, Česká republika, starec@muzeumprahy.cz

PhDr. Jarmila Čiháková, Národní památkový ústav, územní odborné pracoviště v Praze, Na Perštýně 12, 11000 Praha, Česká republika, cihakova.jarmila@npu.cz 
